\title{
FAKTOR-FAKTOR YANG MEMENGARUHI KEPATUHAN IBU HAMIL MENGONSUMSI SUPLEMEN ZAT BESI : SYSTEMATIC LITERATURE REVIEW
}

\section{Factors that Influence the Adherence of Pregnant Women in Consuming Iron Supplements: Systematic Literature Review}

\author{
Juanda Syafitasari, Fitria, Esitra \\ Universitas Aisyiyah Yogyakarta \\ email: juandaanindya@gmail.com
}

\begin{abstract}
ABSTRAK
Latar Belakang: Masalah utama zat besi pada kehamilan adalah kepatuhan, karena perempuan sering gagal untuk mengambil suplemen secara teratur seperti anjuran tenaga kesehatan karena faktor bervariasi dan ini diduga menjadi potensi untuk meningkatkan prevalensi tinggi anemia pada ibu hamil. Tujuan dari systematic review ini adalah untuk mengetahui faktor-faktor yang berhubungan dengan kepatuhan ibu hamil terhadap konsumsi zat besi.

Metode: Studi apprasial menggunakan Joana Briggs Institute (JBI), dan metode sintesis menggunakan modifikasi PEOS.

Hasil: Hasil dari lima jurnal yang memenuhi kriteria inklusi didapatkan faktor-faktor yang mempengaruhi kepatuhan ibu hamil mengonsumsi suplemen zat besi yaitu usia, pendidikan, pekerjaan, pengetahuan, sosio ekonomi, dan kunjungan ANC.

Simpulan: Terdapat hubungan kepatuhan ibu hamil mengonsumsi tablet Fe dengan usia, pendidikan, pengetahuan, kunjungan ANC, pekerjaan paritas, dan paritas. Faktor yang paling berhubungan dengan kepatuhan ibu hamil mengonsumsi tablet Fe adalah frekuensi ANC.
\end{abstract}

Kata Kunci : Kepatuhan, Faktor-Faktor, Konsumsi, Suplement Zat Besi, dan Kehamilan 


\section{ABSTRACT}

Background: The main problem of iron in pregnancy is adherence, because women often fail to take supplement regularly as medical worker recommendation because of various factors and this also thought to be potential to increase high prevalence of anemia in pregnant women. The purpose ofthis systematic review is to find out the factors that are related to pregnant mother adherence towards iron consumption.

Method: This appraisal study used Joana Briggs Institute (JBI), and the sythetic method used PEOS modification.

Results: The result of five journals that fulfills inclusion criteria obtained factors that influence pregnant women adherence in consuming iron supplements that are age, education, occupation, knowledge, socio-economy, and ANC visits.

Conclusion: There are relationship of pregnant women adherence in consuming Fe tablets with age, education, knowledge, ANC visits, occupation parity and parity. Factor those most related to pregnant women adherence in consuming Fe tablets is ANC frequency.

Keywords: Adherence, Factors, Consumption, Iron Supplements, and Pregnancy.

\section{LATAR BELAKANG}

Anemia merupakan masalah kesehatan masyarakat global yang mempengaruhi dua miliar orang di seluruh dunia. Hampir setengah dari semua anak-anak prasekolah, wanita hamil, dan hampir sepertiga dari wanita yang tidak hamil mengalami anemia di seluruh dunia ${ }^{[1]}$. WHO memperkirakan jumlah anemia di seluruh dunia menjadi sangat tinggi (2 milyar) dan sekitar 50\% dari semua anemia dapat dikaitkan dengan kekurangan zat besi. Saat ini, prevalensi global anemia diperkirakan $30,2 \%$ pada wanita tidak hamil naik ke $41,8 \%$ selama kehamilan. prevalensi anemia pada ibu hamil adalah sekitar $24,1 \%$ di Amerika, 48,2\% di Asia Tenggara, 25,1\% di Eropa, 44,2\% di Mediterania Timur, 30,7\% di Pasifik Barat, dan tertinggi di Afrika pada $57,1 \%$. Beberapa penelitian telah melaporkan hubungan anemia selama kehamilan dengan risiko kematian ibu dan hasil kehamilan yang buruk dalam hal berat badan lahir rendah, dan prematuritas, yang merupakan penyebab utama kematian neonatal di negara-negara berkembang. Di Uganda, anemia pada kehamilan diperkirakan mempengaruhi sekitar $33 \%$ dari kehamilan $^{[2]}$.

WHO merekomendasikan bahwa semua wanita hamil harus menerima dosis standar 30-60 mg besi dan $400 \mathrm{mg}$ asam folat selama kehamilan sebagai bagian dari ANC. Banyak negara bertujuan untuk perempuan untuk menerima 90 atau lebih tablet selama kehamilan. Namun, di daerah dimana prevalensi anemia tinggi (> $40 \%$ ), suplementasi yang harus terus selama tiga bulan pada periode postpartum. Intervensi lain seperti makanan, fortifikasi air, dan pengobatan anti-parasit juga menyarankan meskipun efektivitas mereka tidak jelas ${ }^{[1]}$. Menurut Survei Ethiopia Demografi Kesehatan (EDH) 2011, cakupan suplementasi zat besi sangat rendah karena hanya 17,3\% wanita mengambil suplemen selama kehamilan terbaru mereka dalam 5 tahun sebelumnya dan hanya $0,4 \%$ yang dilengkapi selama 90 hari atau lebih. Meskipun asumsi bahwa suplementasi zat besi merupakan bagian integral dari Antenatal Care (ANC), hanya 37\% wanita yang memiliki ANC menerima suplemen zat besi ${ }^{[3]}$.

Salah satu program dari Departemen Kesehatan di Afrika Selatan adalah memasok zat besi untuk semua wanita hamil untuk mencegah anemia sebagaimana direkomendasikan oleh $\mathrm{WHO}^{[4]}$. Banyak negara berkembang saat ini menerapkan program suplementasi zat besi, tetapi hanya beberapa negara telah 
melaporkan peningkatan yang signifikan dalam kontrol anemia dan pencegahan. Semua wanita hamil yang diresepkan suplemen zat besi selama kunjungan ANC mereka. Namun, kurangnya kepatuhan diduga menjadi alasan utama rendahnya efektivitas program suplementasi zat besi. Oleh karena itu penelitian ini dilakukan untuk menyelidiki faktor yang terkait dengan kepatuhan prenatal ${ }^{[5]}$.

\begin{tabular}{|c|c|c|}
\hline \multicolumn{3}{|c|}{ SUBJEK DAN METODE } \\
\hline \multicolumn{3}{|c|}{$\begin{array}{l}\text { Kerangka Kriteria Inklusi dan Kriteria } \\
\text { Eksklusi } \\
\text { Tabel 1. Kerangka Kriteria Inklusi dan } \\
\text { Eksklusi }\end{array}$} \\
\hline PEOS & Kriteria Inklusi & $\begin{array}{l}\text { Kriteria } \\
\text { Eksklusi }\end{array}$ \\
\hline $\mathrm{P}$ & Ibu hamil & Ibu hamil \\
\hline $\mathrm{E}$ & $\begin{array}{l}\text { Faktor yang } \\
\text { mempengaruhi } \\
\text { kepatuhan ibu } \\
\text { hamil } \\
\text { mengonsumsi } \\
\text { suplemen zat } \\
\text { besi }\end{array}$ & $\begin{array}{l}\text { yang } \\
\text { sedang } \\
\text { sakit parah } \\
\text { pada saat } \\
\text { pengumpu- } \\
\text { lan data }\end{array}$ \\
\hline $\mathrm{O}$ & $\begin{array}{l}\text { kepatuhan ibu } \\
\text { hamil } \\
\text { mengonsumsi } \\
\text { tablet Fe }\end{array}$ & \\
\hline $\mathrm{S}$ & Studi Kuantitatif & \\
\hline
\end{tabular}

\section{Pencarian Literatur}

Langkah pertama adalah pencarian kata kunci. Setelah mendapatkan kata kunci kemudian mencari jurnal di database pubmed dan science direct. Langkah kedua adalah pencarian artikel menggunakan reference list dari beberapa artikel yang terkait dengan topik.

\section{Pemilihan Artikel}

Dalam pencarian artikel teridentifikasi 3500 artikel dari database pubmed dan 200 artikel dari database science direct, setelah disaring untuk relevansi didapatkan 14 artikel. Kemudian dilakukan penyaringan artikel lebih lanjut untuk mencari referensi yang tepat dan lengkap mengenai kepatuhan ibu hamil yang mengonsumsi suplemen zat besi dan didapatkan 5 artikel yang akan digunakan untuk Systematic literature Review. Penulis menyaring judul dan abstrak semua artikel untuk dijadikan kriteria inklusi. Studi teks lengkap diambil dan ditinjau secara independen berdasarkan kriteria tersebut. Sehingga meninggalkan 5 artikel untuk dilakukan review akhir.

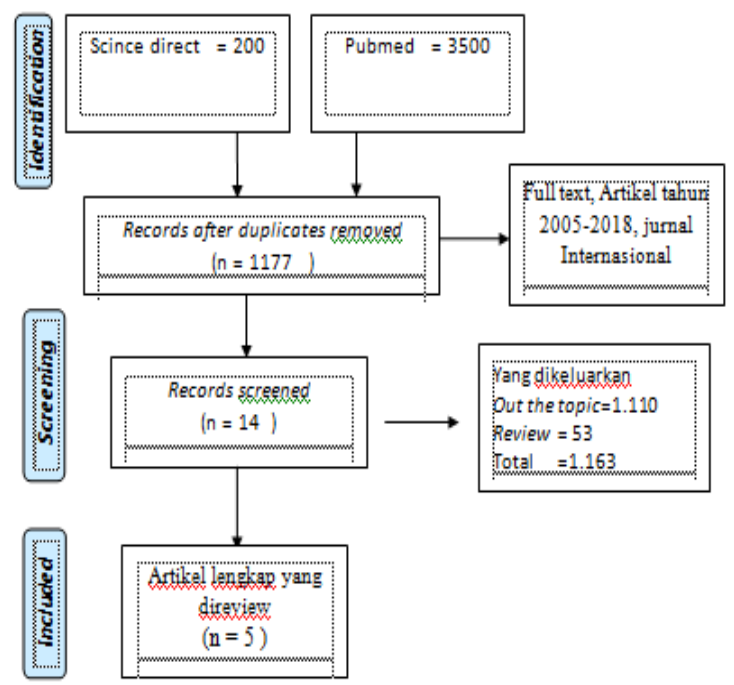

Gambar 1. Langkah Penyusunan

\begin{tabular}{l}
\hline \multicolumn{4}{c}{ HASIL } \\
\hline Hasil Identifikasi dari Search metode \\
pada Pubmed dan Science Direct \\
didapatkan sebanyak 3700 data hasil \\
pencarian. Peneliti melakukan screening \\
diantaranya terdapat hasil tipe data \\
pencarian yang sama dan memiliki \\
kesamaan judul penelitian. Setelah \\
dilakukan tahap screening selanjutnya \\
dilakukan tahap include yaitu kesesuaian \\
data pencarian dengan kriteria inklusi \\
yang telah ditetapkan oleh peneliti \\
diantaranya studi pada kepatuhan ibu \\
hamil mengonsumsi suplemen zat besi, \\
mengetahui faktor-faktor yang \\
mempengaruhi kepatuhan ibu hamil \\
mengonsumsi suplemen zat besi, Full \\
text, artikel tahun 2013-2018, jurnal \\
internasional. Hasil studi didapatkan dan \\
dilakukan screening hingga include untuk \\
mendapatkan dokumen yang sesuai \\
dengan kriteria studi penelitian. \\
Berdasarkan hasil sintesa tersebut \\
didapatkan 5 dokumen yang sesuai
\end{tabular}


dengan kriteria studi dan selanjutnya akan dilakukan analisa mendalam (critical thingking) untuk mendapatkan bukti terbaik dalam mengetahui faktorfaktor yang mempengaruhi kepatuhan ibu hamil mengonsumsi zat besi merupakan penelitian dengan kualitas tertinggi. Hasil literatur penelitian tersebut memiliki kredibilitas yang tinggi dan hasilnya dapat dipercaya. Hasil studi systematic review didapatkan bahwa faktor-faktor yang mempengaruhi kepatuhan ibu hamil dalam mengonsumsi tablet zat besi adalah usia, pendidikan, pengetahuan, kunjungan ANC, pekerjaan, dan sosio ekonomi.

\section{PEMBAHASAN \\ Kunjungan ANC}

Petugas kesehatan mempunyai peran yang sangat penting untuk meningkatkan kepatuhan ibu hamil dalam mengonsumsi suplemen zat besi yaitu dengan cara memberikan pelayanan kepada masyarakat sesuai dengan kebutuhannya, seperti pada saat kunjungan Antental Care pada ibu hamil selain dilakukan pemeriksaan diberikan juga penyuluhan tentang pentingnya mengonsumsi suplement zat besi pada masa kehamilan untuk mencegah terjadinya anemia pada ibu hamil. Tujuan di berikan suplemen zat besi yaitu untuk mencegah terjadinya anemia apabila ibu hamil mengalami anemia dapat menyebabkan meningkatnya risiko keguguran, prematuritas, atau berat bayi lahir rendah (BBLR). Faktor yang memengaruhi kepatuhan ibu hamil dalam mengonsumsi suplemen zat besi yaitu perilaku petugas kesehatan dimana kepatuhan dapat lebih ditingkatkan apabila petugas kesehatan mampu memberikan penyuluhan yang seoptimal mungkin terutama tentang pentingnya mengonsumsi suplemen zat besi pada ibu hamil untuk menjaga kesehatan diri sendiri dan janin yang dikandung.

Kunjungan ANC menyediakan pelayanan untuk ibu hamil dan deteksi dini yang penting untuk kesehatan ibu dan untuk kesehatan janin. Wanita yang memiliki lebih banyak kunjungan ANC memiliki peluang lebih besar untuk menggunakan suplemen zat besi. Karena suplemen zat besi didapat ibu hamil saat kegiatan ANC. Semakin tinggi usia kehamilan, semakin besar kemungkinan ibu melakukan kontak dengan fasilitas pelayanan kesehatan serta mendapatkan suplemen besi dan penjelasan dari petugas kesehatan, sehingga apabila ibu semakin sering melakukan kunjungan ANC diharapkan ibu semakin patuh dalam mengonsumsi tablet $\mathrm{Fe}^{[6]}$. Frekuensi ANC berpengaruh terhadap kepatuhan ibu hamil mengonsumsi tablet Fe. Dengan melakukan pemeriksaan ANC secara rutin minimal 4 kali selama masa kehamilan berguna untuk mengetahui kondisi ibu dan janin sehingga dapat mendeteksi atau mencegah jika ada sesuatu yang dapat membahayakan ibu dan janin ${ }^{[1]}$.

\section{Usia}

Usia merupakan salah satu indikator yang dapat mencerminkan kematangan seseorang dalam melakukan tindakan termasuk dalam pengambilan keputusan. Usia dewasa awal ini dapat menunjukan perilaku positif dalam mempersiapkan masa yang akan datang termasuk dalam menyiapkan sang buah hati sebagai keturunan keluarga yang merupakan tugas dalam menjaga kesehatan diri dan janin yang ada dikandungannya. Disaat usia dewasa awal, pemikiran ibu hamil sudah bisa memilah yang baik dan mampu berfikir untuk kesehatannya dan anak yang dikandungnya dengan konsumsi suplemen zat besi ${ }^{[7]}$.

Salah satu faktor terbukti memiliki hubungan yang signifikan dengan kepatuhan adalah usia peserta. Wanita berusia 35-49 tahun tiga kali lebih patuh mengonsumsi suplemen zat besi daripada wanita dengan usia yang lebih muda (1524 tahun). Alasannya adalah bahwa wanita yang lebih tua mungkin lebih 
peduli tentang kesehatan mereka dan hasil kehamilan, mendapatkan dukungan yang diperlukan dan kerjasama dari anggota keluarga mereka dan memiliki pengalaman yang lebih baik dalam pencegahan dan pengobatan anemia kekurangan zat besi ${ }^{[6]}$.

\section{Pendidikan}

Tingkat pendidikan seseorang akan memengaruhi tingkat pengetahuannya. Semakin tinggi pendidikan ibu hamil maka pengetahuannya tentang gizi akan lebih baik dari yang berpendidikan rendah. ibu hamil yang memiliki pendidikan tinggi akan lebih memahami dan memilih makanan yang berkualitas untuk dikonsumsi sehari-hari. Pemilihan makanan yang bergizi seimbang diharapkan dapat mempengaruhi kesehatan ibu hamil dan janin. Wanita berpendidikan memiliki pengetahuan yang lebih baik tentang anemia kekurangan zat besi dan terapi, pengetahuan yang lebih baik tentang manfaat suplemen dan meningkatkan kekhawatiran tentang hasil kehamilan ${ }^{[5]}$.

\section{Pengetahuan}

Pengetahuan merupakan faktor resiko terjadinya anemia pada ibu hamil. Semakin baik pengetahuan maka akan semakin mudah menerima perubahan perilaku ke arah yang lebih baik $^{8}$. Pengetahuan berhubungan dengan kepatuhan karena pengetahuan merupakan domain yang sangat penting untuk terbentuknya perilaku. Perilaku akan langgeng jika didasari oleh pengetahuan. Pengetahuan yang diperoleh melalui penginderaan ibu hamil terhadap informasi kesehatan selama kehamilan akan berpengaruh terhadap perilaku ibu hamil dalam menjaga kesehatannya. Ibu hamil yang memiliki pengetahuan yang baik tentang suplemen zat besi selama kehamilan 3,5 kali lebih mungkin patuh mengonsumsi suplemen zat besi selama kehamilan dibandingkan dengan mereka yang memiliki pengetahuan yang buruk tentang suplemen zat besi. Alasan adalah pengetahuan yang membantu perempuan untuk memiliki persepsi yang baik tentang pencegahan dan pengobatan anemia selama kehamilan dengan mengonsumsi suplemen zat besi selama kehamilan $^{[9]}$. Wanita yang memiliki pengetahuan yang lebih tinggi tentang anemia hampir empat kali lebih mungkin untuk mematuhi suplementasi zat besi dibandingkan dengan wanita yang memiliki pengetahuan rendah ${ }^{[5]}$.

\section{Pekerjaan}

Sebagai ibu rumah tangga ada keterbatasan bersosialisasi dan interaksi jika dibandingkan ibu yang bekerja. Mereka kurang mendapatkan info tentang kehamilannya khususnya tentang suplemen zat besi. Ibu rumah tangga akan terbatas dalam memperoleh info karena kurang berinteraksi dengan orang, tetapi ibu yang bekerja akan mudah berinteraksi sehingga info tentang tablet $\mathrm{Fe}$ mudah didapa $^{[7]}$. Ibu hamil yang tidak bekerja berarti tidak mempunyai penghasilan sendiri untuk memenuhi kebutuhan sehari-hari dan menjadi tanggung jawab suami. Dengan kata lain ibu yang tidak bekerja cenderung lebih berat beban ekonomi keluarga. Kondisi demikian berpengaruh terhadap rutinitas kunjungan ANC ibu hamil untuk mendapatkan suplemen zat besi dari petugas kesehatan $^{[9]}$. Lingkungan pekerjaan dapat mempengaruhi seseorang memperoleh pengetahuan baik secara langsung dan tidak langsung. Sehingga seseorang dapat memperoleh pengalaman mendapat informasi ${ }^{[3]}$.

\section{Sosio Ekonomi}

Tingkat ekonomi yang kurang memadai untuk memenuhi kebutuhan ibu selama hamil sangat mempengaruhi kehamilan ibu. Jika seorang ibu berada dalam ekonomi yang berkecukupan maka ia akan dapat memenuhi semua kebutuhannya selama hamil terutama 
dalam mengonsumsi makanan ataupun minuman dan sebaliknya, jika ibu berada dalam ekonomi yang kurang ia akan mengutamakan kebutuhan keluarga terlebih dahulu dan tidak memikirkan kebutuhan makanan bagi dirinya sendiri. Para ibu kaya mungkin menganggap mereka kurang rentan terhadap anemia sehingga mengakibatkan mereka memiliki kepatuhan yang buruk. Sehingga prevalensi kejadian anemia lebih tinggi pada wanita kurang beruntung secara ekonomi ${ }^{[4]}$.

\begin{tabular}{l}
\hline SIMPULAN \\
\hline Berdasarkan hasil systematic literature \\
review dan pembahasan yang telah \\
peneliti lakukan mengenai faktor-faktor \\
yang mempengaruhi kepatuhan ibu hamil \\
mengonsumsi suplemen zat besi, maka \\
dapat diambil kesimpulan bahwa umur \\
mempunyai hubungan positif bermakna \\
dengan kepatuhan ibu mengonsumsi \\
suplemen zat besi; pengetahuan \\
mempunyai hubungan positif bermakna \\
berhubungan dengan kepatuhan ibu \\
mengonsumsi suplemen zat besi; \\
pendidikan mempunyai hubungan positif \\
bermakna dengan kepatuhan ibu \\
mengonsumsi suplemen zat besi; status \\
ekonomi mempunyai hubungan positif \\
bermakna dengan kepatuhan ibu \\
mengonsumsi suplemen zat besi; \\
pekerjaan mempunyai hubungan positif \\
bermakna dengan kepatuhan ibu \\
mengonsumsi suplemen zat besi; \\
kunjungan ANC mempunyai hubungan \\
positif bermakna dengan kepatuhan ibu \\
mengonsumsi suplemen zat besi; serta \\
frekuensi kunjungan ANC merupakan \\
variabel yang paling berhubungan positif \\
bermakna dengan tingkat kepatuhan ibu \\
mengonsumsi suplemen zat besi.
\end{tabular}

\section{SARAN}

1. Bidan diharapkan dapat memberikan asuhan pada ibu hamil anemia dengan memberikan pendidikan kesehatan berkala menggunakan lembar balik maupun aplikasi lain akan pentingnya kepatuhan minum tablet besi selama kehamilan sehingga ibu mampu mengkonsumsi tablet besi sesuai anjuran program selama kehamilan.

2. Tenaga kesehatan diharapkan rutin mempromosikan manfaat dari awal dan sering ANC, meningkatkan kualitas konseling ANC termasuk pedoman tentang pengelolaan efek samping dan mempromosikan pengetahuan wanita tentang anemia adalah unsur penting untuk meningkatkan pemanfaatan layanan.

3. Tenaga kesehatan diharapkan memberikan instruksi yang jelas tentang asupan tablet suplemen zat besi dan mendidik mereka tentang manfaat kesehatan dari suplemen zat besi untuk meningkatkan kepatuhan ibu hamil mengkonsumsi suplementasi zat besi.

4. Kepatuhan harus ditingkatkan melalui pendidikan nutrisi, pemantauan dan evaluasi hasil kelahiran di Indonesia untuk menghilangkan anemia terkait efek samping.

5. Peneliti merekomendasikan evaluasi nasional kepatuhan terhadap suplemen zat besi dan mencari cara meningkatkan kepatuhan. Mengembangkan intervensi menargetkan semua wanita hamil dengan meningkatkan cakupan ANC untuk meningkatkan penggunaan suplemen zat besi antenatal.

\section{DAFTAR PUSTAKA}

1. Gebreamlak B, Dadi AF, Atnafu A. 2017. High adherence to iron/folic acid supplementation during pregnancy time among antenatal and postnatal care attendant mothers in Governmental Health Centers in Akaki Kality Sub City, Addis Ababa, Ethiopia: Hierarchical negative binomial poisson regression. PLoS One. 2017; 12(1), h: 1-11. doi:10.1371/journal.pone.0169415. 
2. Nisar Y, D M, Mir aAM. 2014. Factors associated with non-use of antenatal iron and folic acid supplements among Pakistani women. BMC Pregnancy and Childbirth 2014;14(305), h: 1-12.

3. Kiwanuka TS, Ononge S, Kiondo P, Namusoke F. 2017. Adherence to iron supplements among women receiving antenatal care at Mulago National Referral Hospital, Ugandacross-sectional study. BMC Res Notes. $\quad 2017 ; 10(1), \quad$ h: 510. doi:10.1186/s13104-017-2834-z.

4. Gebremedhin S, Samuel A, Mamo G, Moges T, Assefa T. 2014. Coverage, compliance and factors associated with utilization of iron supplementation during pregnancy in eight rural districts of Ethiopia: a cross-sectional study. BMC Public Health. $2014 ; 14, \quad$ h: 607. doi:10.1186/1471-2458-14-607.

5. Taye B, Abeje G, Mekonen A. 2015. Factors associated with compliance of prenatal iron folate supplementation among women in Mecha district, Western Amhara: a cross-sectional study. Pan Afr Med J.
2015; $\quad$ h: $20: 43$. doi:10.11604/pamj.2015.20.43.4894.

6. Ogundipe O, Hoyo C, Østbye T. 2012. Factors associated with prenatal folic acid and iron supplementation among 21,889 pregnant women in northern tanzania: a cross-Sectional HospitalBased Study. Vol 12.; 2012. doi:10.1186/1471-2458-12-481.

7. Alifah NR. 2016. Faktor-faktor yang mempengaruhi ibu hamil mengkonsumsi tablet fe di puskesmas gamping 2 tahun 2016. Program Studi Ilmu Keperawatan Fakultas Kedokteran dan Ilmu Kesehatan Universitas Muhammadiyah Yogyakarta.

8. Notoatmodjo S. 2012. Promosi kesehatan dan perilaku kesehatan. Jakarta: R.

9. Dwi E. 2017. Faktor-faktor yang mempengaruhi kepatuhan ibu hamil dalam mengkonsumsi tablet $\mathrm{Fe}$ di Puskesmas Danurejan 1 Kota Yogyakarta. 2017;12(1), h: 145.

10. Ethiopia Survei Demografi dan Kesehatan Addis Ababa. 